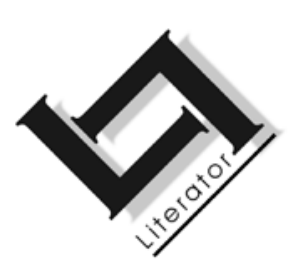

\title{
Possible worlds: a reading of three artworks from the Creative creatures exhibition
}

C. Lotz

School for Communication Studies

Potchefstroom Campus

North-West University

POTCHEFSTROOM

E-pos: colette.lotz@nwu.ac.za

\section{Abstract: \\ Possible worlds: a reading of three artworks from the Creative creatures exhibition}

The basic concern of this article is to offer an interpretation of artworks by a selected group of artists who contributed to the "Creative creatures" project. The original creatures created by the artist, lan Marley, based on narration by his son, Joshua, seem at first glance to suggest an underlying theme of fantasy. However, certain interpretative artworks by artists such as those by Diane Victor, Flip Hattingh and Angus Taylor seem to display a shift from the originally perceived element of fantasy. The artworks rather each represents their own fictional worlds, far removed from the original composite creatures created by Marley who each seems to function in its own fictional world. The superimposition of the incongruous worlds suggests a measure of tension that hinges on progressive notions of archaeology, history and possible worlds.

\section{Opsomming}

Moontlike wêrelde: 'n ontleding van drie kunswerke in die Kreatiewe kreature-uitstalling

Die basiese oogmerk van hierdie artikel is om 'n interpretasie te bied van kunswerke deur 'n geselekteerde groep deelnemers aan die "Kreatiewe kreature"-uitstalling. Die oorspronklike kreature wat deur die kunstenaar lan Marley ontwikkel is, na aanleiding van stories deur sy seun Joshua vertel, weerspieël op 
die oog af 'n onderliggende tema van fantasie. Sekere interpretasies deur kunstenaars soos Diane Victor, Flip Hattingh en Angus Taylor kom egter voor asof dit ver verwyderd is van die oorspronklike element van fantasie. Dit wil lyk asof elke kunswerk sy eie fiktiewe wêreld verteenwoordig, ver verwyderd van die oorspronklike kreature deur Marley, wat oënskynlik op hulle beurt in hulle eie wêrelde funksioneer. Die oormekaarplasing van misplaaste wêrelde bring 'n gevoel van spanning na vore, wat gekoppel kan word aan progressiewe opvattings rakende argeologie, geskiedenis en moontlike wêrelde.

\section{Introduction}

An artwork from each of the three artists (Victor, Hattingh and Taylor) was selected for this investigation on the basis of their unexpected peculiarities in terms of narration, physiological concerns, as well as a sense of history and archaeology. Diane Victor's The Janus frog is a blind embossing executed on paper, whereas Flip Hattingh's Kunstenaarsboek binne takbeeld ("Artist's book within twig sculpture") entails an animal-like structure constructed with twigs which contains a book. In the instance of African Chinese dragon, Angus Taylor built a vessel-like sculpture out of steel, rod and granite. The combination of various animals/humans into fantastic new creatures suggests conflict among their respective worlds, which may also relate to the narrative concept of "worlds colliding". In terms of the interpretation of the original creatures, who each seems to function in their own prehistoric or futuristic fantasy worlds, Victor, Hattingh and Taylor seem to introduce new worlds, which will be further explored in this article.

There is, for example, also evidence of specific geographical and social worlds in many of the artworks. In certain ways parallels can be drawn between the original creatures, relating to the "metanarrative" - the primary story (or rather world) - from which other worlds derived. Precariously, although the physical world of the original creatures is not evident, mainly because of a lack of setting, the implied world of the original creatures does not reflect stability. Rather, it is presented as a fragile constructed world containing fragments (whether overtly or covertly) of both imagination and scientific fact; in itself created knowledge. Almost in the same sense as an archaeological find, the creatures functioned as impetus for further extrapolation. The fictionalised narratives in the three artworks by Victor, Hattingh and Taylor respectively, that derive from 
this metanarrative, constitute "other" worlds - that of the possible and temporal ${ }^{1}$ - containing fictionalised beings and events.

From the above-mentioned observations, the following research questions can be set out:

- How can the concepts of narrative, history and archaeology and worlds be conceptualised in terms of visual artworks?

- How can these concepts be applied to an interpretation of the selected artworks?

\section{Theoretical considerations}

Various salient theoretical concepts came to light in the previous section, namely narratives, worlds, and history (especially with regard to archaeology). These concepts proved to be valuable theoretical instruments in facilitating an investigation into the form and content of the three artworks. This step will lead to deductions being made regarding the representation of various worlds and the zones ${ }^{2}$ or hybrid spaces created as a result of the dialogue between these worlds. The relevance of manifestations of narratives and the fictionality of archaeological and historical "truth" will also be highlighted.

The theoretical premise is thus mainly based on the relevance of the above-mentioned concepts in unlocking interpretative possibilities regarding the form and content of the three artworks. These perspectives all manifest in terms of the historical, psychological, narrational, political and synthetic concerns of postmodernist discourse.

The following section will investigate narratives, as well as the significant links between artistic strategies and narrative conventions that might prove to be valuable tools for interpretation.

1 Temporal elements include for instance "time of the narrating", a key concept coined by Gérard Genette in defining the narrative instance. This refers to the narrative's temporal position with respect to the time of the story narrated. Genette (1996:172-178) undertakes the analysis of narrative tense, studying such temporal aspects as order, duration and frequency.

2 The terms frontier or prototypical zone are, according to McHale (1987:49), what separate binary oppositions such as worlds of "civilisation" and that of the "wilderness". 


\subsection{Narratives}

A narrative, in its broadest sense, is a story ${ }^{3}$ or event, or the representation of a story or event. A narrative text is a text in which an agent relates a story by means of a plot - a scheme consisting of the structures of action and perception which shape the story. Marley, through storytelling, conveys a fiction/reality to the viewer, who gets drawn into the plot by going through the experience with the various characters and their possible stories.

In general, a story or its plot consists of four elements, namely a setting, characters, conflicts and turning points (Klarer, 2007:15). In the first instance the setting deals with answers to the question where. It provides background as to where the story takes place or what kind of world(s) one is dealing with. Furthermore, the characters are introduced in answering who the persons are that are represented in the story. Conflicts are the third important element of a story and answer the question to what is wrong? A "good" story usually begins with a major conflict and then proceeds with more conflicts. Turning points, the last element of a story, are usually structured to resolve some of the conflicts and also give rise to a climactic ending. In other words, an attempt is made to answer the question to what's the remedy? Through the above-mentioned devices a story is told, whether through orature, literature or visual representation. Content in a story or artwork usually remains relative and open-ended and a plurality of interpretation prevails (compare the Barthian continuum of writerly/scribtible and readerly/lisible texts; cf. also Rosenau, 1992:35).

The characters provided by Marley for interpretation might be seen as the metanarrative from which all other narratives resulted. The objective in a postmodern investigative strategy is to divest the metanarrative of its supposed "authority" and to focus on "narrative fragments, usually termed 'micronarratives"' (Godby, 1998:106). In the process of gaining insight into the relationship between social structures through the investigation of narrative fragments, under-

3 Pauline Rosenau (1992:xiv) in her book Post-modernism and the social sciences explains a story or storytelling to entail an explanation that makes no truth claims but admits to being the teller's point of view based only on his/her experience, such as traditional, local narratives. Metanarratives that assume the validity of their own truth claims are criticised by postmodernists, but on the other hand mininarratives, micronarratives, local narratives, traditional narratives - stories that make no truth claims - are more acceptable to postmodernists (Rosenau, 1992:xii). 
lying tensions are usually revealed. The tension present in some of the artists' artworks might thus correspond with the often dubious relationship between metanarratives (such as the prehistoric fantasy world) and micronarratives (interpretative worlds created by Victor, Hattingh and Taylor). A dialogue exists between the abovementioned fictionalised worlds in the three artworks that may directly relate to a strange uneasiness between these different worlds. McHale (1987:57) refers to the space of the interconnection of worlds as an "intertextual zone". It is in this (hybrid) intertextual zone that content presents itself and links between the worlds unfold.

This relationship between the fictional worlds in the artist's three artworks manifests as a major perspective from which this article evolved, as will be elaborated upon in the following subsections.

\subsection{Fictional worlds}

In the previous subsection on narratives it was established that the basic structure of narratives or stories comprises setting, characters, conflicts and turning points. An illusion is usually created that the story on the page (in literary terms or in the surface of an artwork, in the instance of a visual text) is "real" or "true", but according to Marie-Laure Ryan (1991a:554), facts described by the text, whether fictional or not, are presented as actual and others as possible or counterfactual. This gives rise to a system of worlds centred on, what is termed by Ryan (1991a:554), as "the textual actual world".

Within this textual system of reality, alternative possible worlds exist which might belong neither entirely to the realm of fantasy, nor to that of empirical reality. However, these fantastic elements may be linked with the "real", because perceptions of how we understand reality are usually influenced by the external physical world around us and mediated by the teller or artist. These alternative possible worlds may, according to Ryan (1991a:554), include mental representations produced by the characters such as beliefs, wishes, plans, obligations, dreams, fantasies and literary productions. McHale (1987:33) refers to this status of the text between fantasy and reality as being "amphibious", "neither true nor false" and "suspended between belief and disbelief".

Analogies can be drawn between the realms of fantasy and reality in the literary text and those in visual representations. An artwork, such as a text, can also comprise an actual world, or factual domain, surrounded by the "possible worlds" of the character's mental representations that become actualised when they are "read" or inter- 
preted. Ryan (1991b:111) refers to this narrative state, consisting of a constellation of possible worlds, as being a modal system of narration. 4 In the same way it will be illustrated how various real and fictional worlds manifest in the three artworks by Victor, Hattingh and Taylor and how the juxtapositioning or superimposition of such (possibly) incommensurable worlds may result in tension.

The tension in a story might relate to the violation of the boundaries of the different worlds or even the penetration of one world by another. Umberto Eco (cited in McHale, 1992:153) acclaims this kind of violation to the occurrence of "transworld identities". He also reckons the occurrence of these transworld identities to be "a symptom of our uncertainty about the exact boundaries between historical fact and fiction"; conditions that might occur when realworld historical personages, as well as other fictional characters "borrowed" from other fictional worlds, are present in a fictional text (Eco quoted in McHale, 1992:152).

It is clear that entities, including transworld identities, the world of fiction or art and the "real" world, may overlap and even migrate through a "semipermeable membrane" (McHale, 1987:34), resulting in a tangential surface between two worlds. This tangential surface may also be an "ambiguous or liminal space", termed by McHale $(1987: 49)$ as a "frontier" or "prototypical zone". The existence of these zones can often be attributed to the occurrence of allusions a reference, often only implicit or indirect, to another work of literature, art, person or event (Bennett \& Royel, 1995:206; Bal, 2001:69).

$4 \quad$ Ryan, in her investigations into the relations between possible worlds of theory and narrative semantics, distinguishes between four different types of "modal constraints" that structure narrative worlds. The alethic, made up of the operators possible, impossible and necessary, is shown to be responsible for the division of the population of fictional worlds into groups of different abilities (e.g. gods versus humans), as well as for the categorisation of fictional worlds as a whole as realist, fantastic, or nonsensical. Constraints of the deontic type generate plots of obligation, crime and punishment formed by the concepts of permission, prohibition, and obligation. The axiological system underlies stories of quest and moral dilemma (goodness, badness and indifference), and the manipulation of the categories of the epistemic system, such as knowledge, ignorance and belief, produces mystery stories, narratives of learning, comedies of error, and the all-important function of deceit (Ryan, 1991b:111). 


\subsection{Archaeology (History)}

Narratives closely relate to history since conventional history can be understood as a continuum of events or stories. As opposed to the "seamless narrative of the past, on the one hand, and the rational analysis of structures, on the other" (Godby, 1998:106), perceptions of historical writing have changed dramatically and the perception of history as the very opposite of fiction is no longer tenable. Rosenau (1992:63) suggests that postmodernists generally question:

... (1) the idea that there is a real, knowable past, a record of evolutionary progress of human ideas, institutions, or actions, (2) the view that historians should be objective, (3) that reason enables historians to explain the past, and (4) that the role of history is to interpret and transmit human cultural and intellectual heritage from generation to generation.

The field of interest of historical narration has shifted to the postmodern notion of heterogeneity and multiplicity. History in the postmodernist sense now serves to present the complexity and contradiction of historical experience, and the existence of diverse realities is hereby acknowledged. Meaning is not lodged in a chain of events themselves, but in the writer or reader's interpretation of these events. The process of analysis seems to relate to the systematic uncovering of strata in the archaeological excavation of a historical site. On the other hand, the process may also relate to the uncovering of memories of the past.

The existence of diverse realities and worldviews can relate to the notion that perception and artistic are recreations of "reality" and here memories may be regarded as recycling processes, which seem to be the case in the three artists' interpretations of the creatures. Linda Hutcheon explains that the discursive nature of all reference, both literary and historiographical, means that the referent is always already inscribed in the discourse of our culture (Hutcheon, 1988:119). She furthermore acknowledges that the past did exist, independently of our capacity to know it, which links this view to historiographic metafiction.

Historiographic metafiction accepts the philosophically realist view of the past and then proceeds to confront it with an antirealist one that suggests that, however true that independence may be, nevertheless the past exists for us - now - only as traces on and in the present. The absent past can only be inferred from circumstantial evidence. (Hutcheon, 1989:73.) 
Even if barriers between the present and the past are frequently transgressed in postmodern fiction (and art), the boundaries remain, even if they are constantly challenged. Postmodernist artworks relating to history (archaeology) expose the possible seam between fact and fiction and elucidate the tension between these worlds (McHale, 1992:152).

In some regards the content of the artworks by Victor, Hattingh and Taylor, seems to comply with "historiographic metafiction" in the sense that the subject matter includes characters and events from "known" history, which are mediated by the artist, fictionalised, fragmented and represented in the form of narratives. Iconographical reference can be made in terms of allegories, stories and images, relating to the narrative analysis of the story or the signified in Mieke Bal's terms.

In summary, the concepts of character and narrative worlds, history and archaeology, transgression of boundaries and intertextuality function in postmodern texts in order to disturb the relationship between fiction and reality or "truth". The next section will present a method in which these concepts can be addressed in the interpretation of the selected artworks.

\section{A model for interpreting the artworks}

This reading of the selected artworks from the Creative creatures exhibition by Victor, Hattingh and Taylor entails an exploration of their form, content and context. In arriving at a method of investtigation, I considered formal and structural elements in the interpretation of artworks as proposed by art historians such as Erwin Panofsky (1970) and Edmund Burke Feldman (1991). These models are mainly lodged in Western art history and have been subjected to criticism for being too formalist or for claiming a universal applicability for their theories. The writings of Wayne Booth in The rhetoric of fiction (1983) were also considered although he was also criticised in terms of his formalist views. He viewed form and content as inseparable and showed interest in the ways in which narrative content is constructed and represented.

The interpretation, then, is mostly concerned with conceptual content, which will be preceded by a short enquiry into formal aspects of the individual artworks, also with reference to relevant conventions. In many ways analogies can be drawn here between the way in which a writer of fiction uses character, setting, plot, point of view, theme and various kinds of symbolism and language and the way 
that an artist uses form, colour, line, perspective, and other elements of visual art to create an artwork. These formal elements and conventions create intertextual structures, identified as content, which in this case is argued to be various fictional worlds.

The narratives of the fictional worlds can relate to Bal's three basic levels of narrative analysis - fabula, story and text (Bal, 2001:4247). These levels, in broad terms, link firstly with a formal analysis into text which, according to $\mathrm{Bal}$, refer to the recognition of a finite and structured set of linguistic signs. Furthermore, the story refers to the signified of a narrative text and the story signifies, in turn, a fabula (Gennette, 1996:6). Bal, well-known for her development of the term focalisation, 5 explains that the fragmented elements of the fabula does not form a coherent whole as such, but that the relationship between the text and its content (the fabula) can only be established by the mediation of an intermediary layer, the "view" of the events (Bal, 2001:46). This relationship is a component of the story, and this of the content of the narrative text. Parallels can be drawn here with iconographical analysis, as set out by Panofsky in his pivotal book Meaning in the visual arts (1970). In this stage of interpretation he proposes explorations into conventional subject matter, "constituting the world of images, stories and allegories" (Panofsky, 1970:40). Although Bal advises that the concept of intertextuality seems close to that of iconography, she insists that compromises in analysis of artworks should not be made in terms of the examination of the reuse of earlier forms, patterns and figures (Bal, 2001:68). ${ }^{6}$ Nonetheless, because of the identifiable analogies

Focalisation refers in general to the relationship between the elements presented - that which is "seen" or perceived - and the vision through which they are seen or presented (Bal, 2001:43).

According to Bal three features distinguish intertextuality from iconography. In the first place, iconographic analysis sees the historical precedent as a source that virtually dictates to the later artist what forms can be used. By adopting forms from the work of a predecessor or from tradition, the later artist declares his allegiance and debt to, and eventually competition with, a prestigious predecessor, whose trace is inscribed in the later work. Secondly, iconographic analysis generally avoids making statements about the meaning of borrowed motifs, since visual artists may borrow motifs without borrowing meaning. The later artist may reject or reverse, ironise or deconstruct, pluralise or marginalise the meaning of the borrowed motif, but that meaning cannot be undone, ignored or cancelled out. A third difference resides in the textual character of intertextual allusion. By reusing forms taken from earlier works, an artist both carries with him the text from which the borrowed element has broken away and constructs a new text from the debris. 
between the artworks and fictional narration, visual narratology can be embraced in the analysis of visual imagery.

It will firstly be demonstrated how Victor, Hattingh and Taylor, through the use of formal structuring devices, set up disparate worlds next to each other. The section on content will mainly consider narratives in the form of images, stories, myths and allegories. Narratives will be considered as the determining perspective for investigations into content. Explorations into the plots of the three artworks will include the recognition of the various characters, their stories, as well as themes permeating the three artworks. The dialogue between worlds and settings within the three artworks will, furthermore, be investigated.

In summary, the methodological strategy will involve a focus on the form and content of the artworks. The first stage of investigation into form will explore formal elements and conventions, including the "direct content of visual signifiers" (Bal, 2001:54) to propose the structure of possible fictional worlds. Secondly, considerations involving the content of the artworks will involve the exploration of the stories, myths or narrative structures involving the main figures. In terms of focalisation, content relates to the story - the layer between the text and the fabula. The incorporation of theoretical considerations regarding narratives, fictional worlds, history and archaeology will form part of the reading.

\section{The reading}

\subsection{Formal aspects}

Diane Victor has established herself as a renowned artist in South Africa and abroad, especially in terms of her technical mastery of graphic media and her intense responses to social injustices through the use of her idiosyncratic iconography (Von Veh, 2008:50,89). Besides Victor's interests in the physiological and physical interaction between people in previous exhibitions, she also displays interest in the disintegration of belief systems. This theme manifests in a recent exhibition, Extinct beliefs, in the form of fossilised remains of dinosaurs. It does not seem peculiar that her interpretation of the creatures also correlates with such physical aspects of fantastic skeletons of for instance an angel - a therianthrop - manifesting in the above mentioned series (Shaman, 2008). In the instance of The Janus frog, Victor interpreted the creature (Fig. A) as being in a fossil state. The only difference is that the skeleton did not harden in rock but has been fossilised in paper. 
Figure A: The Janus frog (Diane Victor, 2007)

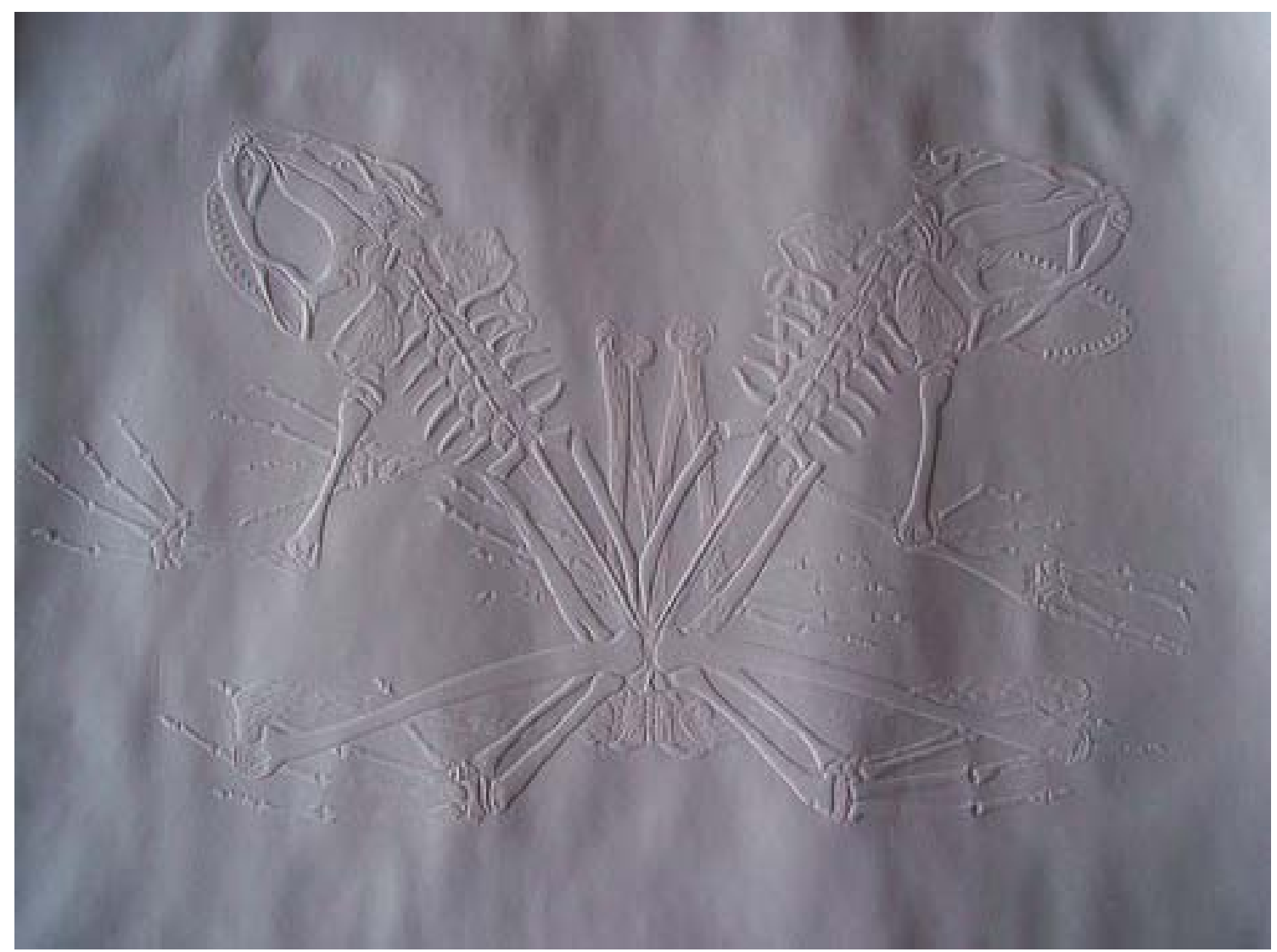

Through the process of blind embossing, an image that resembles the skeletal remains of The Janus frog was created in paper. This printing procedure entails the placing of paper onto cut plate shapes and rolling it through a printing press under high pressure. The effect is colourless with images only emerging in shadow in the paper, depending on the angle of lighting. The appearance of the artwork is that of intriguing serenity and remembrance or even anticipation of a fantastic possible world. The froglike creature, constituting two amphibians joined at their backs like Siamese twins, is reflected almost exactly in relief in the artwork of Victor in the form of an " $X$ ". This reminds one of the Rorschach inkblot test 7 reflecting organic forms

7 The Rorschach inkblot test was developed in the 1920s by Hermann Rorschach, a young Swiss psychologist who got the idea from a popular European parlor game that involved making inkblots and telling stories about them. Like all projective tests, the Rorschach presents viewers with ambiguous images and asks them to interpret the images, thereby eliciting their thoughts, fears, motives, and fantasies. The ten symmetrical inkblots used in the test (five contain color, five are black and gray) are always the same, given in a specific order, and are supposed to be kept secret from the public to ensure "spontaneous" 
and used by psychologists to evaluate dimensions of emotional response. The possibility exists that Victor might have used this technique to set the viewer's emotional response into motion in the viewing of the artwork and set the stage for further analysis.

Flip Hattingh, in Kunstenaarsboek binne takbeeld (Fig. B), created a sculpture woven with twigs and a book placed inside the structure. The structure seems to relate to a skeleton. Although it is not obvious from which specific creature the skeleton has been derived, its shape correlates with Choppy, a creature with two legs in front ending in webbed toes, and two back legs ending in hooves. The creature has a pointy tail with sharp fins and a long head that ends in a sharp beak.

Hattingh stated that he was inspired by basket weavers when creating Kunstenaarsboek binne takbeeld. He did not set out to create a skeleton, but instead he wanted to create a basket in which a creature could fit - an outline of the space where the creature could have been. The sculpture does not stand upright, but is presented as lying down, communicating a passiveness towards the internal meaning it contains. The book is handmade, with traces of stencilling and stains on its pages. The void where the creature "should" be is filled with the artist's book. The use of twigs lends an organic quality to the artwork, which contributes to a sense of fragility. The possibility of deterioration by means of rotting seems inevitable. Even in the instance of the artist's book, the handmade qualities of the pages contribute to the sense of degeneration. Alternatively, the possibility exists that the memories contained within the book may be preserved due to the fact that they are enclosed between sturdy covers.

answers that give clues to people's personalities - and personality disorders (Loftus, 2001). 
Figure B: Kunstenaarsboek binne takbeeld (Flip Hattingh, 2007)

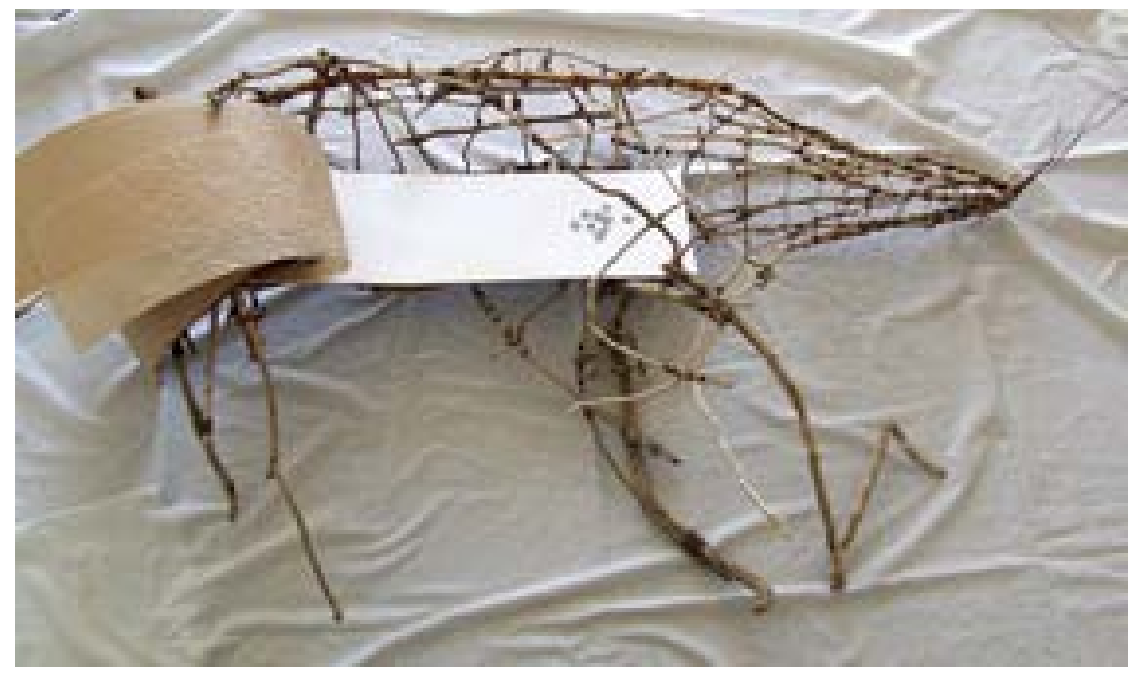

The text of this artwork thus constitutes an artist book within a twig structure derived from one of the original creatures. The original creature might be perceived as the textual actual world around which all other possible worlds presented in this artwork centres.

Angus Taylor, on the other hand, created a vessel-like sculpture with wheels (Fig. C) that does not, at first glance, seem to relate to any of the original creatures. He seems to have created a new composite creature constituting two cast buffalo heads at the opposite ends and a "body", which is made from cast carbon steel, mild steel rods and granite from a quarry in Belfast. The weight of both ends of the sculpture is carried by cables extending from two vertical supports, which may suggest a bridge.

The title of the work, African Chinese dragon, does not relate clearly with the traditional, mythological image of a dragon. Rather, in reference to the buffalo heads and Belfast granite, allusions to a hybrid creature are implied. Diverse realities in character are also implied in the combination of a variety of materials. Each piece of steel rod, carbon casting, or block of granite carries the history and traces of its origin and processing, setting up possible worlds within this sculpture. The elongated structure relating to that of a bridge might also be a sign signifying a frontier or zone where possible worlds can connect. 
Figure C: African Chinese dragon (Angus Taylor, 2007)

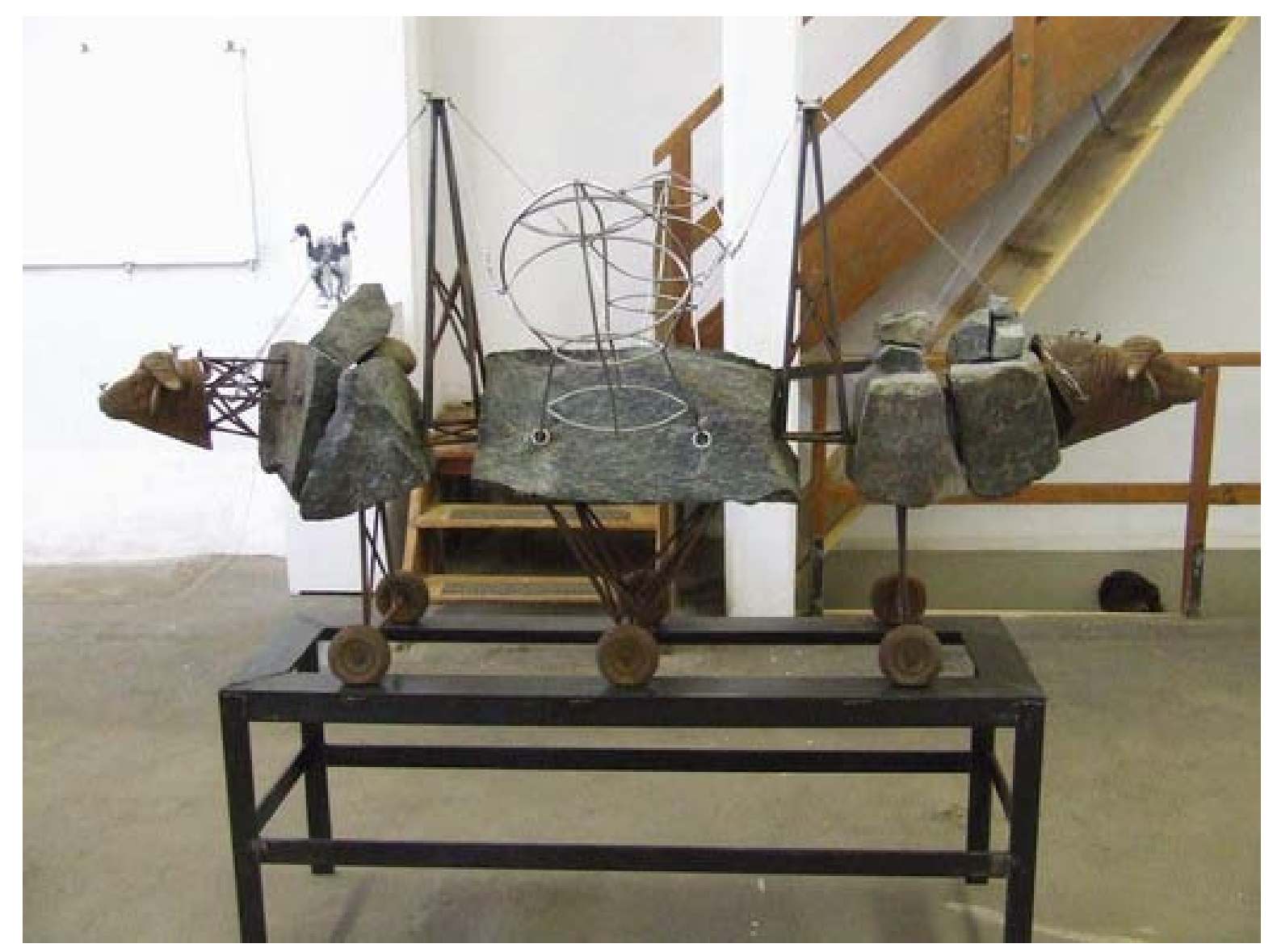

\subsection{Content}

Various salient concepts and theoretical constructions, namely narratives, fictional worlds and history (archaeology) were briefly discussed above in terms of their relevance to this study. Applying these concepts to the reading of the three artworks, through a process of decoding, may prove valuable in unlocking possibilities of how various forms of narration manifest in these artworks.

\subsubsection{Characters, setting and plots}

In the respective artworks, The Janus frog, Kunstenaarsboek binne takbeeld and African Chinese dragon, various characters came to light in the formal investigation, whether overtly or covertly. The obvious character of the froglike creature in The Janus frog appears to be the single protagonist, which tells the story of a past long forgotten. It seems as if this image could have been more appropriately displayed in a glass showcase in a natural history museum.

Through the process of embossing, traces were left of an ancient creature set in paper and not in stone as expected. The artwork, 
with its tactile appearance and devoid of colour, seems to function without a setting. The bones are mysteriously stripped of a world in which to function. It becomes a memory of what once was.

The composite creature seems incongruous to the world as we know it. This gives rise to a notion that the creature may have functioned in a different, possible world and it's fossilised remains was recently rediscovered. In a sense the creature exists in the realm between fact and fiction. Because of the lack of information about the creature, the truth is being imagined. This notion complies with McHale's (1987:33) view that the blurring of boundaries between the realm of fantasy and empirical reality becomes "amphibious", "inbetween" fantasy and reality and is neither necessarily true nor false. When considering the term amphibious, it also becomes clear that, besides the notion of fluctuation between perceived reality and fantasy, the term also refers to an animal living both on land and in water. This opens up a new set of questions about the nature of the ancient world in which the original, froglike amphibious creature functioned. Mystical in character, that world still seems possible, as suggested by Victor.

Another possible world is revealed in the sculpture by Flip Hattingh. As established, the skeletal structure of one of the original creatures by Marley (Choppy) manifests as main character in Kunstenaarsboek binne takbeeld. Constructed with twigs, the structure reminds of a fossil unearthed by archaeologists. Although Hattingh did not intend the shape to represent an ancient skeleton of the creature, such a reading is implied. In that sense, the structure becomes the possible, fictionalised world of the creature, the space in which history and memories may be conceived and perceived. It reminds one of the fabula in which the basic outline of all the elements such as characters, conflicts and turning points forms a framework for the implied story. The notion that form and content can not function apart, as according to Booth (1983), becomes very evident in this instance.

Construed in the mind of the viewer, the world of the creature is imagined. Because of the loosely woven nature of the sculpture, gaps were left between the twigs. It is almost as if it is expected of the viewer to "fill in the gaps". This may be achieved by weaving a story around what is possible and what is probable. The gaps also contribute to the sense of fragility of the sculpture and the possibility that memories may "slip between the gaps" which, in turn, represent an unstable world. 
The space or void left by the implied creature leaves room for other narratives to emerge. The story contained within the pages of the artist's book is not written in words, but is metaphorical. The book is biographical in nature (as stated by the artist), and resembles a memento mori to the artist's deceiced father. Traces of memories are conceived in the evidence left within the pages of the book in the form of stains and stencilling. Although the viewer does not necessarily share in those memories, a sense of history is inevitable. The blank areas on the pages leave room for reminiscence, almost as if the viewer is transported to a time and world long past. Thus, the world "inside" the creature, represented by the book, contains a possible world, that of reminiscence. It functions on a personal level and is intended to be envisaged by the viewer.

On a more universal level, as the title suggests, African Chinese dragon by Angus Taylor, refers to a hybrid creature with both African and Chinese characteristics. This composite creature presents a network of intertextually rich references. In the first instance, Taylor's general concern with mythology has become evident in earlier exhibitions and is also the main theme of this sculpture.

Dragons have for centuries been conceived as fearsome, mystical creatures with special powers. Contradictory to this, the dragon in Chinese mythology is perceived as a symbol of light and of imperial might (Van Reeth, 1994:69). They are regarded as wise, spiritual beings, omens of happiness and prosperity and also possess the ability to undergo transformation. According to Taylor (artist's statement), the Asian dragon is a long snake-like animal that controls water, whilst the Western dragon - a four-legged creature - controls fire. Nonetheless, a measure of conflict is inevitable between these binary oppositions of fire and water, fearsomeness and happiness.

The presentation of the sculpture as a vessel-like creature on wheels furthermore discloses the artist's fascination with mythology. The theme refers to the story of the Trojan horse. According to legend, the Greeks conquered Troy by crafting a beautiful vessel, a horse, and leaving it outside the gates of Troy. The Trojans, under the impression that the Greeks withdrew from combat, pulled the vessel into the city. At night, soldiers hiding inside the horse escaped and opened the gates for the Greek army to enter. The reason why mythical status has been bestowed on this true event is possibly because of the strong moral lesson it entails: "in a situation of conflict, never let down your guard", or "perseverance will be rewarded". A simple action, infringing on the vulnerabilities of a nation, gave rise to the demise of a city. 
As opposed to the previous two artworks by Victor and Hattingh, African Chinese dragon may relate to ancient history, but not necessarily to prehistory. The structure does not remind of an organism to be rediscovered in an archaeological dig. The ridged steel constructions are man-made and the buffalo heads neatly executed. The granite from a quarry in Belfast was carefully selected and contains untold stories of its own.

In the three artworks, various characters were identified that represent their own worlds, that in a sense also relate to the various settings. In the instance of Victor's The Janus frog, the froglike creature's skeletal imprint suggests its (lost) presence and thus functions as the underlying character. The setting constitutes a possible world construed in the imagination of the viewer, a world in-between fact and fiction.

Hattingh created a third space for reminiscence. The implied space where the character (creature) was or should have been, becomes a world in its own, where narratives can be imagined - a space of reminiscence. For the artist, the same space functions as a biographical world, filled with memories of his deceased father. The creature and the possibility of its existence, on the other hand, represent a prehistoric fictional world, suspended between fact and fiction.

In Taylor's African Chinese dragon, as in the instance of Hattingh's Kunstenaarsboek binne takbeeld, gaps are left in the structure to be filled in the imagination of the viewer. Intertextual references imply that a definite merging of East and West took place: the "dragon" took on African characteristics. The character or main protagonist is thus a hybrid creature constued with borrowed motifs. By means of inevitable cross-pollination, new (postmodern) identities are constantly shaped. Boundaries between worlds are becoming blurred. Analogies can be drawn between the fragmentary nature and multiplicity of postmodern-localised narratives and that of postmodern culture at large.

In the spaces of reminiscence, the viewer is confronted with his/her own narratives and identity and the hybrid nature of this identity becomes clear. In a sense, this process also relates to archaeological fiction in which layers are pealed off to arrive at, what might be, the "truth". Angus Taylor seems to understand that postmodern culture constitutes and results in diversity, hybridity and multiplicity. 


\section{Conclusion}

The investigation into the three artworks by Victor, Hattingh and Taylor revealed various analogies, as well as disparities in terms of form and conceptual content.

It has been demonstrated how different narrative worlds have been set up next to each other. The juxtapositioning of images relating to archaeological fiction and the subjective fantasy world proved to create tension, but this conflict between worlds as narrative strategy was found to be essential in any story.

The major conflict in the three artworks seemed to hinge on the uncertainty between fact and fiction. History and archaeology, in a conventional sense, have for centuries been perceived as "true" and "cultured". 8 The creatures, on the other hand, present us with an ancient or prehistoric world of fantasy and uncertainty. The juxtapositioning of such worlds creates frontiers of tension. Analogies exist, especially in terms of semantics, between frontiers found in fictional worlds, and military frontiers between groups at war. An intertextual reference to war is evident in Taylor's African Chinese dragon. The vessel, reminding of the Trojan horse, becomes a frontier in its own right. In Taylor's instance, the frontier is between Eastern and Western conventions. Illuminating the idea of a frontier, the critic and literary historian, Richard Chase, describes the characteristics of a frontier as

... a kind of border fiction, whether the field of action is between civilization and the wilderness ..., or whether the field of action is conceived not so much as a place as a state of mind - the borderland of the human mind where the actual and the imaginary intermingle (Chase cited in McHale, 1987:49).

Not only is the "untamed" and "primitive" being violated by a world of "civilisation", but the superimposition of this world inevitably gives rise to conflict. That might be the reason why Hattingh and Taylor left physical and implied gaps in their sculptures and Victor confronts the viewer with a lifeless fossil embossed in pristine white paper, in which fictional and historial narratives can be imagined. What is described by Chase above as "a state of mind", might thus relate to

8 History as metanarrative conventionally considered the universal destiny of "man" to progress from a state of nature (relating to primitivist thinking) to a state of culture (embodied in the concept of civilisation; relating to the condition and process of achieving refinement and order) (Young, 1995:32). 
the notion that a space of reminiscence exists in the boundaries of the worlds in all three artworks. The different fictional worlds overlap with each other and ontological boundaries are violated, resulting in intertextual zones. It is in these zones between the realms of fantasy and empirical reality that new histories have been construed.

In Victor's The Janus frog, archaeological suggestion is that the fossilised creature probably did exist. The viewer is placed in the position of the archaeologist who rediscovered the find and should uncover the past.

In Hattingh's Kunstenaarsboek binne takbeeld a definite progression can be traced when compared with Victor's artwork in terms of its archaeology. Hattingh's work suggests that an archaeological find was reconstructed in twigs. The artist's intention, on the other hand, was to create a zone for reminiscence - itself a concept that suggests layers of memory. Various transworld identities emerged in this space where the implied creature prevailed. The artist recreated a sense of the prehistoric creature and of the possible world in which it dwells, as well as of memories of the artist's father. This multifunctioning space also presents a zone of reminiscence for the viewer in which memories can be recalled and new histories can be imagined.

Taylor's African Chinese dragon entailed the creation of a new hybrid identity, as a result of the borrowing from the archaeological fictionalised world, as well as from mythological "truths". A shared transworld identity was created as a result of the uncertainty of the boundaries between historical fact and fiction. It has been proved that various zones have been created as a result of the overlapping of the incongruous worlds of fiction and the "real". Within these tangential frontiers, narrative conflict is inevitable.

The postmodern condition of micronarratives, fictionalised worlds and history manifests in these three works. In conclusion, critic Kim Levin's statement is relevant:

Tolerant of ambiguity, contradiction, complexity, incoherence, it is eccentrically inclusive. It [postmodernism] mimics life, accepts awkwardness and crudity, takes an amateur stance. Structured by time rather than form, concerned with context instead of style, it uses memory, research, confession, fiction - with irony, whimsy and disbelief. Subjective and intimate, it blurs the boundaries between the world and the self. It is about identity and behaviour. (Levin, 1985:1.) 


\section{List of references}

BAL, M. 2001. Looking in: the art of viewing. Amsterdam: $G$ \& B Arts International.

BENNETT, A. \& ROYEL, N. 1995. An introduction to literature, criticism and theory: key critical concepts. London: Prentice-Hall.

BOOTH, W. 1983. The rhetoric of fiction. Chicago: University of Chicago Press.

FELDMAN, E.B. 1991. Varieties of visual experience. New York: Abrams.

GENNETTE, G. 1996. Voice. (In Onega, S. \& Garcia Landa, J.A., eds. Narratology. London: Longman. p. 172-189.)

GODBY, M. 1998. Memory and history in William Kentridge's "History of the main complaint". (In Nuttall, S. \& Coetzee, C., eds. Negotiating the past: the making of memory in South Africa. Cape Town: Oxford University Press. p. 100-112.)

HUTCHEON, L. 1988. A poetics of postmodernism: history, theory, fiction. London: Routledge.

HUTCHEON, L. 1989. The politics of postmodernism. London: Routledge.

KLARER, M. 2007. An introduction to literary studies. London: Routledge.

LEVIN, K. 1985. Farewell to modernism. (In Hertz, R., ed. Theories of contemporary art. Englewood Cliffs: Prentice-Hall. p. 1-9.)

LOFTUS, M.J. 2001. The Rorschach inkblot test. Emory magazine. http://www. emory.edu/EMORY_MAGAZINE/summer2001/rorshach.html Date of access: 19 Jan. 2009.

McHALE, B. 1987. Postmodernist fiction. London: Routledge.

McHALE, B. 1992. Constructing postmodernism. London: Routledge.

PANOFSKY, E. 1970. Meaning in the visual arts. Harmondsworth: Penguin.

ROSENAU, P.M. 1992. Postmodernism and the social sciences. Princeton: Princeton University Press.

RYAN, M. 1991a. Possible worlds and accessibility relations: a semantic typology of fiction. Poetics today, 12(3):553-576.

RYAN, M. 1991b. Possible worlds, artificial intelligence and narrative theory. Indiana: University Bloomington \& Indianapolis Press.

SHAMAN, S. 2008. All smoke and mirrors. Art South Africa. http:/l artsouthafrica.com/?article=614 Date of access: 9 May 2008.

VAN REETH, A. 1994. Ensiklopedie van die mitologie. Vlaeberg: Vlaeberg.

VON VEH, K. 2008. Gothic visions: violence, religion and catharsis in Diane Victor's drawings. (In Rankin, E. \& Von Veh, K. Diane Victor. Parkwood: Krut. p. 50-95.)

YOUNG, R. 1995. Colonial desire: hybridity in theory, culture and race. London: Routledge.

\section{Key concepts:}

archaeology

fictional worlds

Hattingh, Flip

hybrid spaces

possible worlds

Taylor, Angus

Victor, Diane 
Kernbegrippe:

argeologie

fiksiewêrelde

Hattingh, Flip

hibridiese ruimtes

moontlike wêrelde

Taylor, Angus

Victor, Diane 
